\title{
Zinc oxide nanoparticles alleviate the arsenic toxicity and decrease the accumulation of arsenic in rice (Oryza sativa L.)
}

Shiwei Yan ${ }^{1 \dagger}$, Fan $\mathrm{Wu}^{1 \dagger}$, Song Zhou', Jianhao Yang ${ }^{1}$, Xianjin Tang ${ }^{2^{*}}$ and Wenling Ye $\mathrm{e}^{1,2^{*}}$

\begin{abstract}
Background: Rice is particularly effective, compared to other cereals, at accumulating arsenic (As), a nonthreshold, class 1 human carcinogen in shoot and grain. Nano-zinc oxide is gradually used in agricultural production due to its adsorption capacity and as a nutrient element. An experiment was performed to explore the effects of zinc oxide nanoparticles $(\mathrm{nZnO})$ on arsenic (As) toxicity and bioaccumulation in rice. Rice seedlings were treated with different levels of $\mathrm{nZnO}(0,10,20,50,100 \mathrm{mg} / \mathrm{L})$ and $\mathrm{As}(0$, and $2 \mathrm{mg} / \mathrm{L})$ for 7 days.

Results: The research showed that $2 \mathrm{mg} / \mathrm{L}$ of As treatment represented a stress condition, which was evidenced by phenotypic images, seedling dry weight, chlorophyll, and antioxidant enzyme activity of rice shoot. The addition of $\mathrm{nZnO}(10-100 \mathrm{mg} / \mathrm{L})$ enhanced the growth and photosynthesis of rice seedlings. As concentrations in the shoots and roots were decreased by a maximum of 40.7 and $31.6 \%$ compared to the control, respectively. Arsenite [As (III)] was the main species in both roots (98.5-99.5\%) and shoots (95.0-99.6\%) when exposed to different treatments. Phytochelatins (PCS) content up-regulated in the roots induced more As (III)-PC to be complexed and reduced As (III) mobility for transport to shoots by $\mathrm{nZnO}$ addition.
\end{abstract}

Conclusion: The results confirmed that $\mathrm{nZnO}$ could improve rice growth and decrease As accumulation in shoots, and it performs best at a concentration of $100 \mathrm{mg} / \mathrm{L}$.

Keywords: Arsenic, Zinc oxide nanoparticle, Toxicity, Speciation, Rice

\footnotetext{
* Correspondence: xianjin@zju.edu.cn; wlye@ahau.edu.cn

†'Shiwei Yan and Fan Wu are co-first author.

${ }^{2}$ Key Laboratory of Environment Remediation and Ecological Health

(Zhejiang University), Ministry of Education, Hangzhou 310058, China

Anhui Province Key Laboratory of Farmland Ecological Conservation and

Pollution Prevention, School of Resources and Environment, Anhui

Agricultural University, 130 Changjiang West Road, Hefei 230036, Anhui, P.R.

China
}

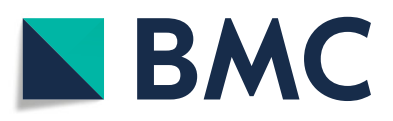

() The Author(s). 2021 Open Access This article is licensed under a Creative Commons Attribution 4.0 International License, which permits use, sharing, adaptation, distribution and reproduction in any medium or format, as long as you give appropriate credit to the original author(s) and the source, provide a link to the Creative Commons licence, and indicate if changes were made. The images or other third party material in this article are included in the article's Creative Commons licence, unless indicated otherwise in a credit line to the material. If material is not included in the article's Creative Commons licence and your intended use is not permitted by statutory regulation or exceeds the permitted use, you will need to obtain permission directly from the copyright holder. To view a copy of this licence, visit http://creativecommons.org/licenses/by/4.0/. The Creative Commons Public Domain Dedication waiver (http://creativecommons.org/publicdomain/zero/1.0/) applies to the data made available in this article, unless otherwise stated in a credit line to the data. 


\section{Background}

Arsenic (As) is a carcinogenic metal that enters the body primarily through drinking water and diet, which increases human health risks and attracts global attention [1]. Human activities increase the concentration of arsenic in soil and water, thereby increasing the concentration of arsenic in crops [2]. Paddy rice (Oryza sativa L.) is particularly efficient in As uptake from paddy soil due to rice plants' unique ability [3, 4]. Elevated As accumulation in rice has the potential to become a new disaster for the population in Southeast Asia [5], it is important to reduce the accumulation of arsenic in rice.

It has been reported that arsenic poisoning of plants will lead to shorter rhizomes, reduced biomass and inhibited photosynthesis [6]. Khan et al. found that both the biomass and length of Indian mustard root and stem were reduced under arsenic treatment [7]. Szilvia et al. found that excessive uptake of arsenic reduced chlorophyll content of maize and sunflower leaves [8]. In addition, plants under As stress produce a large amount of reactive oxygen species (ROS) [9]. As also exacerbates the extent of cell membrane damage caused by membrane lipid peroxidation [10].

Nanoparticles (NPs) show great potential in the remediation of soil and water pollution for their high surface area, gap structure and unique property [11]. It's reported that kinds of NPs can reduce the damage of toxic metals to plants. For instance, $\mathrm{CuO}$ NPs enhanced the growth and decreased As accumulation in rice [12]. In addition, $500 \mathrm{mg} / \mathrm{kg}$ multiwall carbon nanotubes have been reported to alleviate $\mathrm{Cd}$-induced toxicity by promoting plant growth [13].. Singh et al. found that $\mathrm{TiO}_{2}$ NPs application reduced $\mathrm{Cd}$ toxicity of the soybean plants by increasing the photosynthetic rate and growth parameters [14]. In recent years, $\mathrm{nZnO}$ have been widely used as crop nutrients in zinc-deficient areas. $\mathrm{nZnO}$ had the positive effects on plant growth and physiology [15, 16]. What's more, the positive impacts of $\mathrm{nZnO}$ on alleviation of $\mathrm{Cd}$ accumulation in several plant species have been reported [17-20]. To date, the impact of $\mathrm{nZnO}$ on the plant growth and As uptake of rice exposed to As stress is rarely studied. Wang et al. recently researched the effects of $\mathrm{nZnO}$ on As uptake, but the As concentration treated was $1 \mathrm{mg} / \mathrm{L}$, at which concentration rice growth wasn't affected significantly [21]. In addition, only one $\mathrm{nZnO}$ dose $(100 \mathrm{mg} / \mathrm{L})$ application was researched in the experiments. Therefore, a $\mathrm{Zn}$ doseresponse curve is needed to find the optimal concentration of $\mathrm{nZnO}$ which can reduce the As toxicity.

Seed germination and the early seedling growth are more sensitive to metal pollution, and the early seedling growth are important considerations in toxicity assessment [22]. In this experiment, the growth and physiological characteristics of rice seedlings $(30 \mathrm{~d})$ were studied to evaluate the effects of $\mathrm{nZnO}(10-100 \mathrm{mg} / \mathrm{L})$ on As stress, including dry weight, chlorophyll content, root cell membrane integrity, leaf antioxidant enzyme activity and As accumulation in rice. It's assumed that $\mathrm{nZnO}$ can reduce the toxicity of As in rice by promoting the growth and reducing the concentration of As in rice seedlings. In this study, the effects of different doses of nano-zinc oxide on physiological status and arsenic accumulation in rice were investigated to better understanding the mechanism and optimal dosing of nanozinc fertilizer to reduce arsenic concentration in plants. This study will provide a new insight to nanomaterials' possible application in environmental remediation.

\section{Materials and methods Chemicals}

$\mathrm{nZnO}$ was purchased from Nanjing XFNANO Material Technology Co., Ltd. with a purity of $99 \%$. Scanning electron microscopy (SEM) was used to observe that $\mathrm{nZnO}$ were mostly spherical, with a particle size of 20$30 \mathrm{~nm}$ and a specific surface area of $21.50 \mathrm{~m}^{2} / \mathrm{g}$. Sodium arsenite $\left(\mathrm{NaAsO}_{2}\right)$ was purchased from Aladdin Chemical Co., Ltd.

\section{Experiment design}

Rice seeds (Liangyou 8106) were purchased from Win-all Hi-tech Seed Co., Ltd. The collection of plant material comply with national guidelines and legislation. The seeds were surface-sterilized with $0.5 \%$ $\mathrm{NaOCl}$ solution for $15 \mathrm{~min}$, washed with deionized water and then soaked for $1 \mathrm{~h}$ with deionized water [23]. After seed germination, rice seedlings were transferred to pots containing $1 \mathrm{~L}$ Kimura nutrient solution [24]. There were two rice seedlings per pot. The pots were placed randomly in a growth cabinet at $25^{\circ} \mathrm{C}, 16 \mathrm{~h}$ photoperiod with a light intensity of $350 \mu \mathrm{mol} / \mathrm{m}^{2}$ s. The nutrient solution in the pots was renewed every 3 days.

Rice seedlings cultivated with Kimura nutrient solution for 30 days were used as experimental materials. Pour out the nutrient solution and dilute the prepared As and $\mathrm{nZnO}$ stock solutions into the pot to obtain the target gradient treatment. $\mathrm{NaAsO}_{2}$ was added to prepare Asspiked solution with As concentration of $2 \mathrm{mg} / \mathrm{L}, \mathrm{nZnO}$ was applied to prepare test solution of $0,10,20,50,100$ $\mathrm{mg} / \mathrm{L} \mathrm{Zn}(\mathrm{nZnO})$. The $\mathrm{nZnO}$ suspension was sonicated by ultrasonic vibration $(100 \mathrm{w}, 40 \mathrm{KHz})$ for $45 \mathrm{~min}$ to increase dispersion. The treatments were as follows (As concentration $(\mathrm{mg} / \mathrm{L}))+\mathrm{nZnO}$ concentration $(\mathrm{mg} / \mathrm{L}))$ : As; As+nZnO10; As+nZnO20; As+nZnO50; As+ nZnO100. Treatments with no As and $\mathrm{nZnO}$ were controls. Each treatment was repeated 3 times. 


\section{Biomass}

Rice seedlings were harvested after exposure to treatments for 7 days. The roots were soaked with a $10 \mathrm{mM}$ ethylenediaminetetraacetic acid solution for $10 \mathrm{~min}$ and then washed with distilled water 3 times. After washing the above-ground part of each rice with distilled water, the two rice seedlings in each pot were treated separately. One was kept fresh to measure chlorophyll content, antioxidant enzyme activities, and electrolyte leakage. The other one was oven-dried at $75^{\circ} \mathrm{C}$ for $72 \mathrm{~h}$ to constant weight.

\section{Chlorophyll content}

The harvested fresh rice leaf sample was cut into pieces, $0.1 \mathrm{~g}$ sample was weighed into a centrifuge tube, and 10 $\mathrm{ml}$ of $95 \%(\mathrm{v} / \mathrm{v})$ ethanol was added. After being left in the dark for $14 \mathrm{~h}$, the absorbance of the supernatant was measured with a UV-422G spectrophotometer at wavelengths of $649 \mathrm{~nm}$ and $665 \mathrm{~nm}$. Use the formula (1) and (2) to calculate chlorophyll a (Chl a) and chlorophyll b (Chl b), separately [25]. Total chlorophyll is the sum of chlorophyll a and chlorophyll b.

$$
\begin{aligned}
& \text { chlorophyll } \mathrm{a}= \\
& \begin{aligned}
& \left(13.95 A_{665}-6.8 A_{649}\right)(\mathrm{mg} / \mathrm{L}) \\
& \times 10 \\
& \times 10^{-3}(\mathrm{~L}) / \text { fresh weight }(\mathrm{g}) \\
\text { chlorophyll b }= & \left(24.96 A_{649}-7.32 A_{665}\right) \\
\text { total chlorophyll }= & \text { chlorophyll a } \\
& + \text { chlorophyll b }
\end{aligned}
\end{aligned}
$$

\section{Determination of antioxidant enzyme activities}

Fresh shoot and root samples were used for testing the antioxidant enzyme activities and Phytochelatins (PCs) content, respectively. Fresh samples $(0.5 \mathrm{~g})$ were weighed and grounded in liquid nitrogen, then added $5 \mathrm{ml} 0.01$ $\mathrm{mol} / \mathrm{L}$ PBS buffer solution ( $\mathrm{pH} 7.0$ ). The $0.01 \mathrm{~mol} / \mathrm{L} \mathrm{PBS}$ buffer solution was prepared by mixing dissolving $7.9 \mathrm{~g}$ $\mathrm{NaCl}, 0.2 \mathrm{~g} \mathrm{KCl}, 0.24 \mathrm{~g} \mathrm{KH}_{2} \mathrm{PO}_{4}$, and $1.8 \mathrm{~g} \mathrm{~K}_{2} \mathrm{HPO}_{4}$ in 1 $\mathrm{L}$ deionized water. The homogenate was centrifuged at $20,000 \times g$ for $20 \mathrm{~min}$. Then the supernatant was collected to determine the activity of catalase (CAT), superoxide dismutase (SOD), and PCs as described before [26]. The specific method is as follows, $10 \mu \mathrm{L}$ supernatant was added to testing wells which already contain $40 \mu \mathrm{L}$ sample dilution. The wells were incubated for $30 \mathrm{~min}$ at $37{ }^{\circ} \mathrm{C}$ after closing plate with closure plate membrane. Then, $50 \mu \mathrm{L}$ HRP-conjugate reagent was added to each well, except blank well. Chromogen solution A and chromogen solution B were added to each well for 15 min at $37^{\circ} \mathrm{C}$. Subsequently, the stop solution was added to each well to stop the reaction. Finally, we take the blank well as zero and read absorbance at $450 \mathrm{~nm}$ after adding the stop solution within $15 \mathrm{~min}$.

\section{Electrolyte leakage}

Electrolyte leakage was measured using root samples to compare the change of cell membrane permeability. The procedure of determination was based on the method used before [27]. After the roots were rinsed, a certain amount ( $0.5 \mathrm{~g})$ of fresh root sample was weighed and placed in a $50 \mathrm{ml}$ test tube, and $30 \mathrm{ml}$ of distilled water was added and shaken in a constant temperature shaker $\left(25^{\circ} \mathrm{C}\right)$ for $1 \mathrm{~h}$ to determine the initial conductivity $\mathrm{EC}_{0}$. Then the root samples were boiled for $10 \mathrm{~min}$ to destroy the membrane permeability. The final electrical conductivity (ECt) was measured after equilibration at $25^{\circ} \mathrm{C}$. Electrolyte leakage $(\%)=\left(\mathrm{EC}_{0} / \mathrm{EC}_{\mathrm{t}}\right) \times 100 \%$.

\section{Detection of As and $\mathrm{Zn}$ concentration in different tissues of rice}

The total As and $\mathrm{Zn}$ in plant tissues were determined by strong acid digestion. Approximately $0.5 \mathrm{~g}$ of dry root and dry shoot were added into a $5 \mathrm{~mL}$ high-purity $\mathrm{HNO}_{3} / \mathrm{HClO}_{4}$ $(87 / 13, v / v)$ and sat overnight at room temperature for predigestion. Total As and $\mathrm{Zn}$ concentrations in the samples were analyzed using ICP-MS (Agilent 7500ce). We used the GBW10023 (GSB-14) for standard reference material. The recovery for reference material was $86.5-97.3 \%$.

\section{As speciation analysis}

For determination of As speciation in rice tissues, fresh rice samples were grounded by liquid nitrogen. $0.25 \mathrm{~g}$ materials were extracted using a $20 \mathrm{~mL}$ PBS solution for $1 \mathrm{~h}$ with sonication. The PBS solution contained $2 \mathrm{mM} \mathrm{NaH}_{2} \mathrm{PO}_{4}$ and 0.2 $\mathrm{mM} \mathrm{Na}$-EDTA (pH 6.0). The extracts were filtered through $0.45 \mu \mathrm{m}$ filters as described previously [28]. For quality assurance, we added a certified reference material (NIST 1568a rice flour) and included blanks. The recovery for reference material was 88.4-109.1\%. High Performance Liquid ChromatographyInductively Coupled Plasma Mass Spectrometry (HPLC-ICPMS; 7500a Agilent Technologies) was used for As speciation.

\section{Translocation factor of As in Rice}

Translocation factor (TF) of As was defined as the ratio of As concentration in shoots to that in roots [23], as described below:

$$
\mathrm{TF}=\frac{\text { As concentra tion in shoots }(\mathrm{mg} / \mathrm{kg})}{\text { As concentra tion in roots }(\mathrm{mg} / \mathrm{kg})}
$$

\section{Statistical analysis}

Statistical analysis was performed using Microsoft Excel 2010 and SPSS-19.0 software. The statistical difference among control and treatments was determined using one-way ANOVA multiple comparison. Data were compared by Duncan's test. Differences were considered significant at $p \leq 0.05$. Pearson correlation analysis was performed by SPSS to quantify the relationships between $\mathrm{Zn}$ concentration and As concentration in rice. 


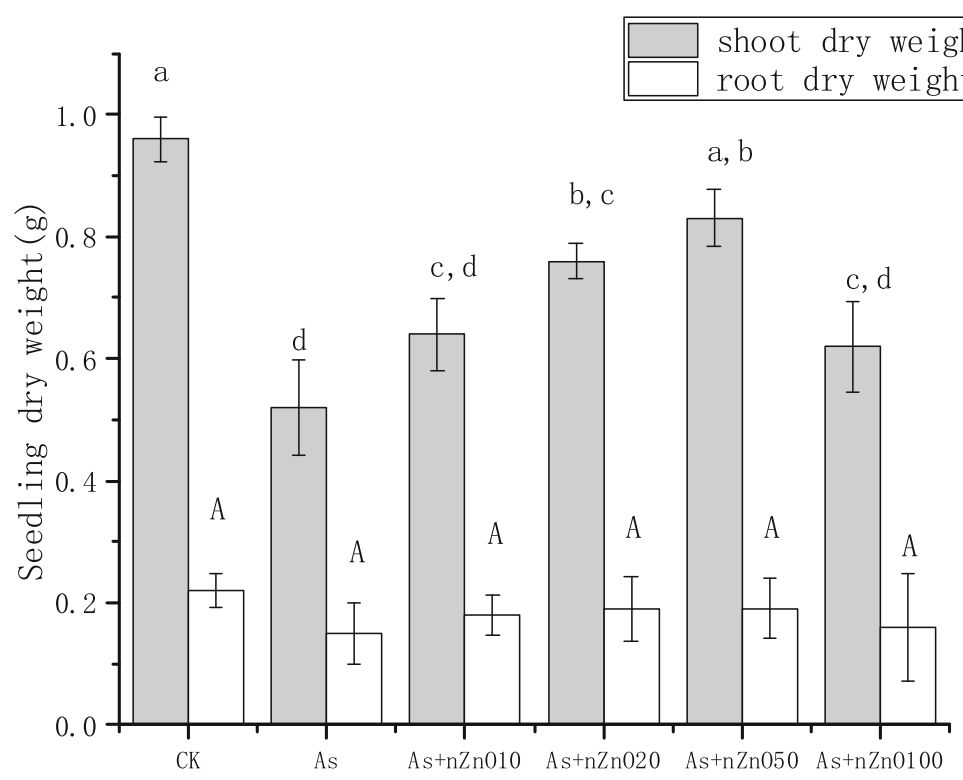

Fig. 1 Biomass of the shoots and roots of rice seedling grown in different treatments

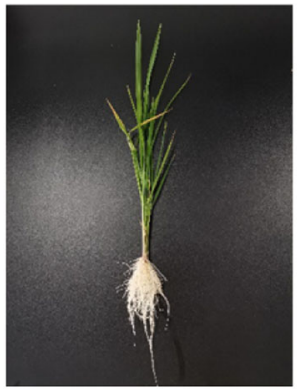

CK

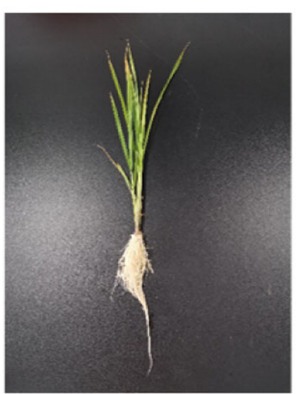

As+nZnO20

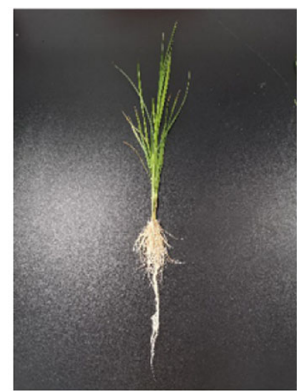

As

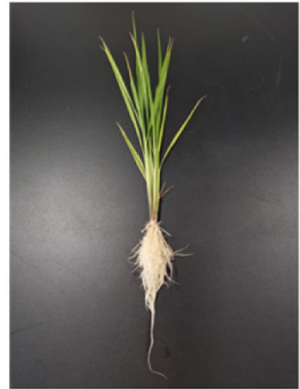

As $+n Z n O 50$

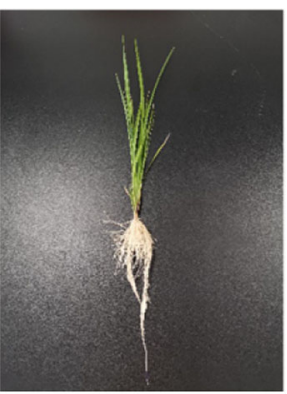

$\mathrm{As}+\mathrm{nZnO10}$

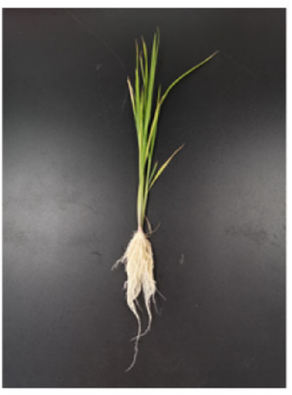

As+nZnO100

Fig. 2 Phenotypic images of rice seedlings after 7 days of growth in different treatments 


\section{Results}

\section{Growth analysis}

To investigate the impacts of $\mathrm{nZnO}$ on rice seedlings growth under As stress, rice growth parameters were recorded and depicted in Figs. 1 and 2. It's showed that 2 $\mathrm{mg} / \mathrm{L}$ As treatment greatly reduced the dry biomass of shoots. The addition of $\mathrm{nZnO}(10-100 \mathrm{mg} / \mathrm{L})$ improved the rice resistance to As toxicity, increasing the biomass of shoots and roots by $19.2-59.6 \%$ and $6.7-26.7 \%$, respectively. The shoot dry weight was almost closed to the control when applied with $50 \mathrm{mg} / \mathrm{L} \mathrm{nZnO}$.

\section{Chlorophyll content}

Chlorophyll is an important substance for plants to absorb sunlight for photosynthesis, and its content affects the growth rate of plants. As shown in Fig. 3, the chlorophyll content of rice leaves treated with $2 \mathrm{mg} / \mathrm{L}$ arsenic was significantly decreased (27.3\%) compared to the control $(p<0.05)$. After application with $\mathrm{nZnO}$, the chlorophyll concentration increased by $2.7-20.3 \%$. Similarly to the shoot biomass, the chlorophyll content was most in the As+nZnO50 treatment and had no significant difference with control $(p>0.05)$.

\section{Change of the cell membrane permeability}

Electrolyte leakage was used to analyze membrane permeability. Figure 4 shows that As treatment induced obvious electrolyte leakage, increasing the electrolyte leakage by 1.75 times compared with control, from 8.8 to $15.4 \%$. The addition of $\mathrm{nZnO}$ significantly increases the electrolyte leakage. And with the increase of concentration of $\mathrm{nZnO}$ treatment, the electrolyte permeability also gradually increases. Especially for the As+nZnO100 treatment, the electrolyte leakage increased to $31.8 \%$, indicating that the addition of $\mathrm{nZnO}$ will synergize with As to change the permeability of the cell membrane.

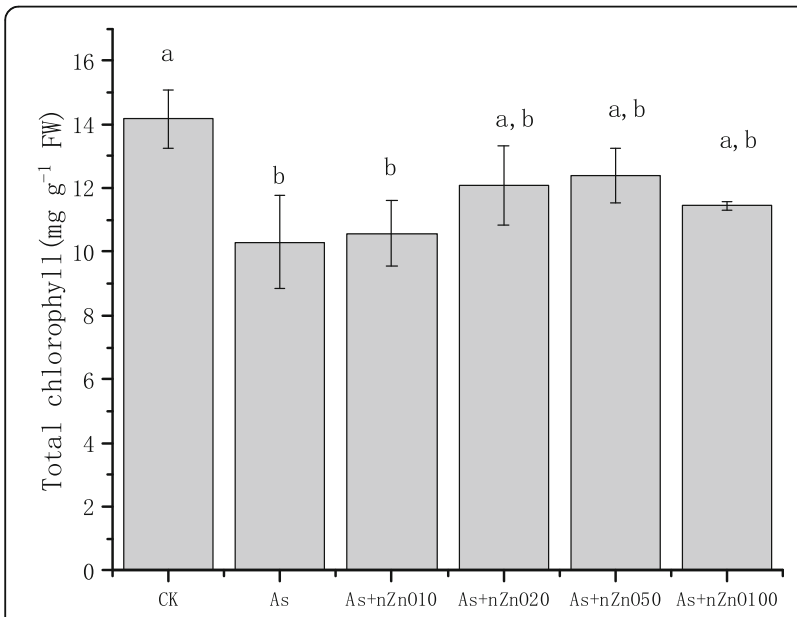

Fig. 3 Effect of $\mathrm{nZnO}$ on Chlorophyll content under As stress

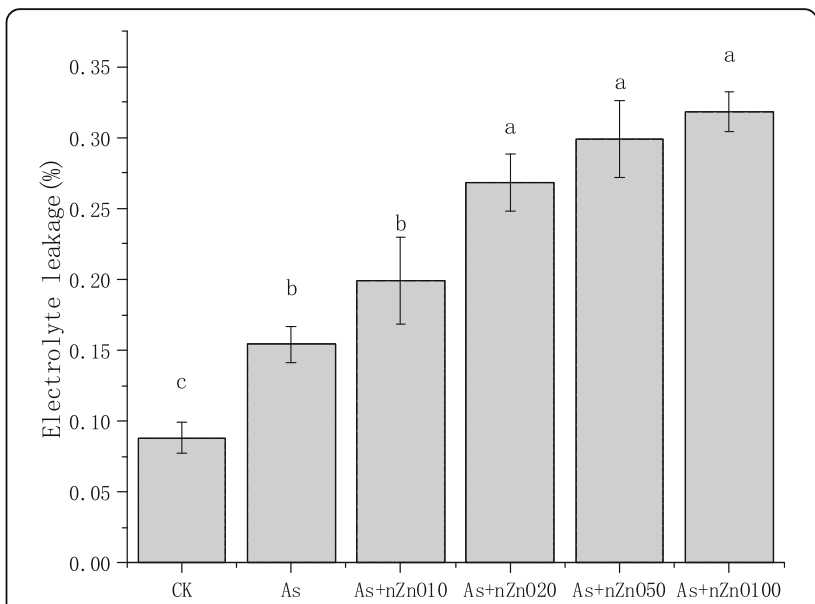

Fig. 4 Structural damage to the plasma membrane

\section{Antioxidant enzyme activities of rice shoot}

To determine how the presence of $\mathrm{nZnO}$ affects the toxicity of As on plants, the changes of SOD and CAT activity in rice shoots exposed to different treatments for 7 days were studied. Results showed that the SOD activity in shoots decreased by $34.46 \%$ in $2 \mathrm{mg} / \mathrm{L}$ As treatment compared to that of control (Fig. 5a). SOD activity was increased by $35.34,17.13,16.71$ and $26.37 \%$, respectively, for As+nZnO10, As+nZnO20, As+nZnO50 and As $+\mathrm{nZnO} 100$ treatments than As treatment. Especially in the $20 \mathrm{mg} / \mathrm{L} \mathrm{nZnO}$ treatment, SOD activity has returned to normal levels. The change in CAT activity is shown in Fig. 5b. There was no significant difference in CAT activity between the different treatments $(p>0.05)$.

\section{Uptake of As and $\mathrm{Zn}$ in rice tissues}

The concentrations of As and $\mathrm{Zn}$ in plant tissues are shown in Figs. 6 and 7. Application of $\mathrm{nZnO}$ decreased the As contents in rice shoots by $14.3-40.7 \%$ (Fig. 6a). But in the roots, the effects of $\mathrm{nZnO}$ application on As accumulation were different, which depended on the $\mathrm{nZnO}$ dose application (Fig. 6b). $10 \mathrm{mg} / \mathrm{L}$ and $20 \mathrm{mg} / \mathrm{L}$ $\mathrm{nZnO}$ addition didn't decrease the As concentration, while $50 \mathrm{mg} / \mathrm{L}$ and $100 \mathrm{mg} / \mathrm{L}$ treatments decreased the As concentration by 25.6 and $31.6 \%$, respectively, in rice roots. TF of As in different treatments were calculated (Table 1). The results showed different concentration applications of $\mathrm{nZnO}$ significantly decreased the TF values. In all treatments, As (III) was the main species in both roots (98.6-99.3\%) and shoots (95.01-99.58\%), as showed in Table 2. nZnO caused little impact on the As (III) species percentage in rice roots $(p>0.05)$ but significantly reduced As (III) percentage in rice shoots $(p<$ $0.05)$. Moreover, $\mathrm{Zn}$ concentration in shoots and roots was also determined (Fig. 7). Zn content in rice roots and shoots were promoted with the application of $\mathrm{nZnO}$ increased. After calculating, we found that As 

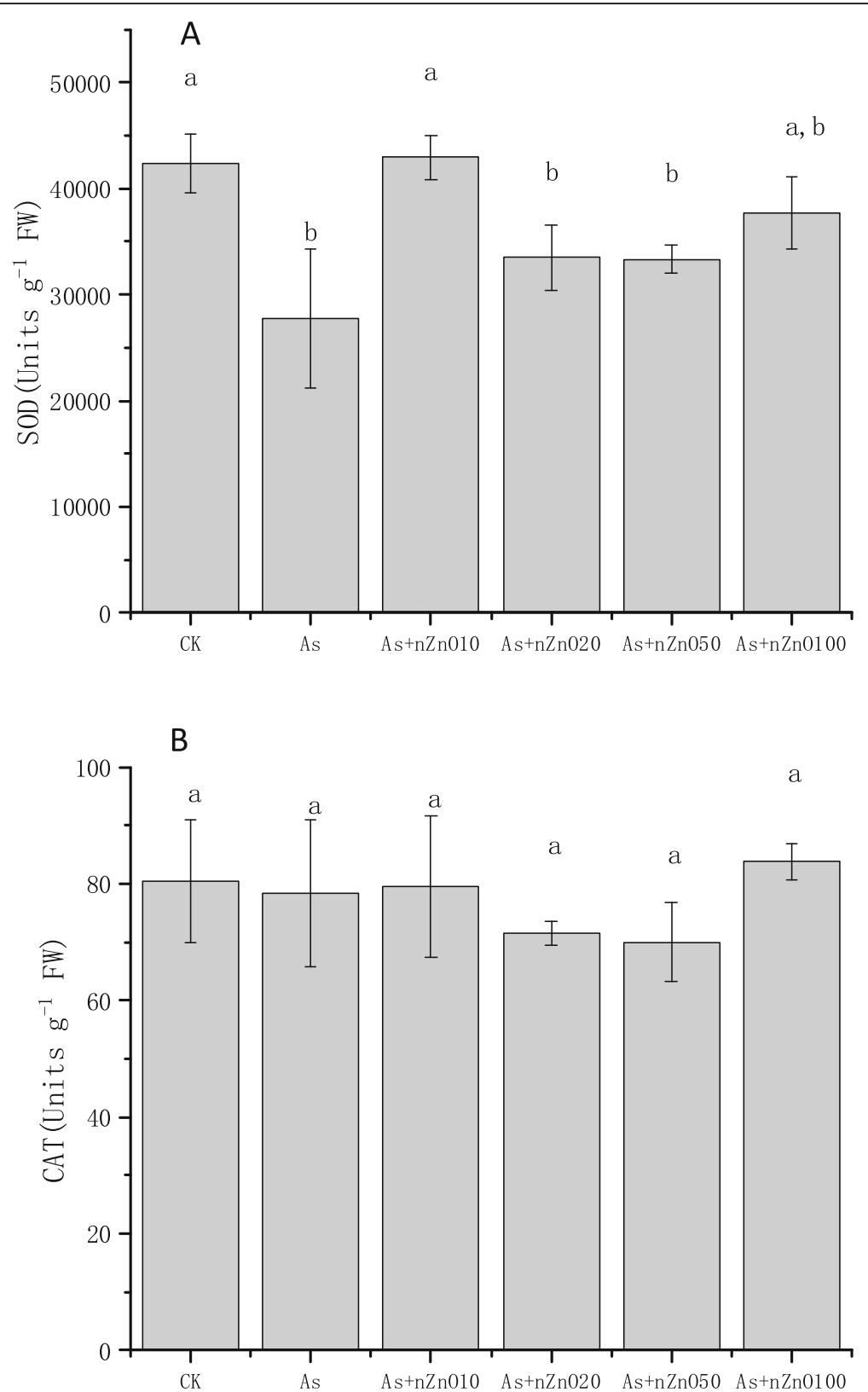

Fig. 5 Effects of different treatments on SOD (a) and CAT (b) activities in rice leaves

concentration had a negative correlation with $\mathrm{Zn}$ concentration in rice shoots, and the Pearson correlation coefficient was -0.973 .

\section{PCs content of rice root}

For further understanding As transport in rice plants, PCs content in rice roots were researched (Fig. 8). PCs content in rice root was $115.5 \mathrm{ng} / \mathrm{L}$ when treated with 2 $\mathrm{mg} / \mathrm{L}$ As. $\mathrm{nZnO}$ application $(10-100 \mathrm{mg} / \mathrm{L})$ significantly promoted PCs content by $8.2-24.1 \%$.

\section{Discussion}

In this study, we researched the effects of different concentrations of $\mathrm{nZnO}$ on the rice growth and As accumulation under hydroponic conditions, to test whether $\mathrm{nZnO}$ can be used as an environmental-friendly agrichemical to reduce As toxicity in rice. This experiment shows that the application of $\mathrm{nZnO}$ can promote the rice biomass under As stress, especially for the treatment of As+nZnO50 (Fig. 1). Our early germination experiments also showed that low concentration of $\mathrm{nZnO}(10$, $20 \mathrm{mg} / \mathrm{L}$ ) amendment increased the shoot length by 

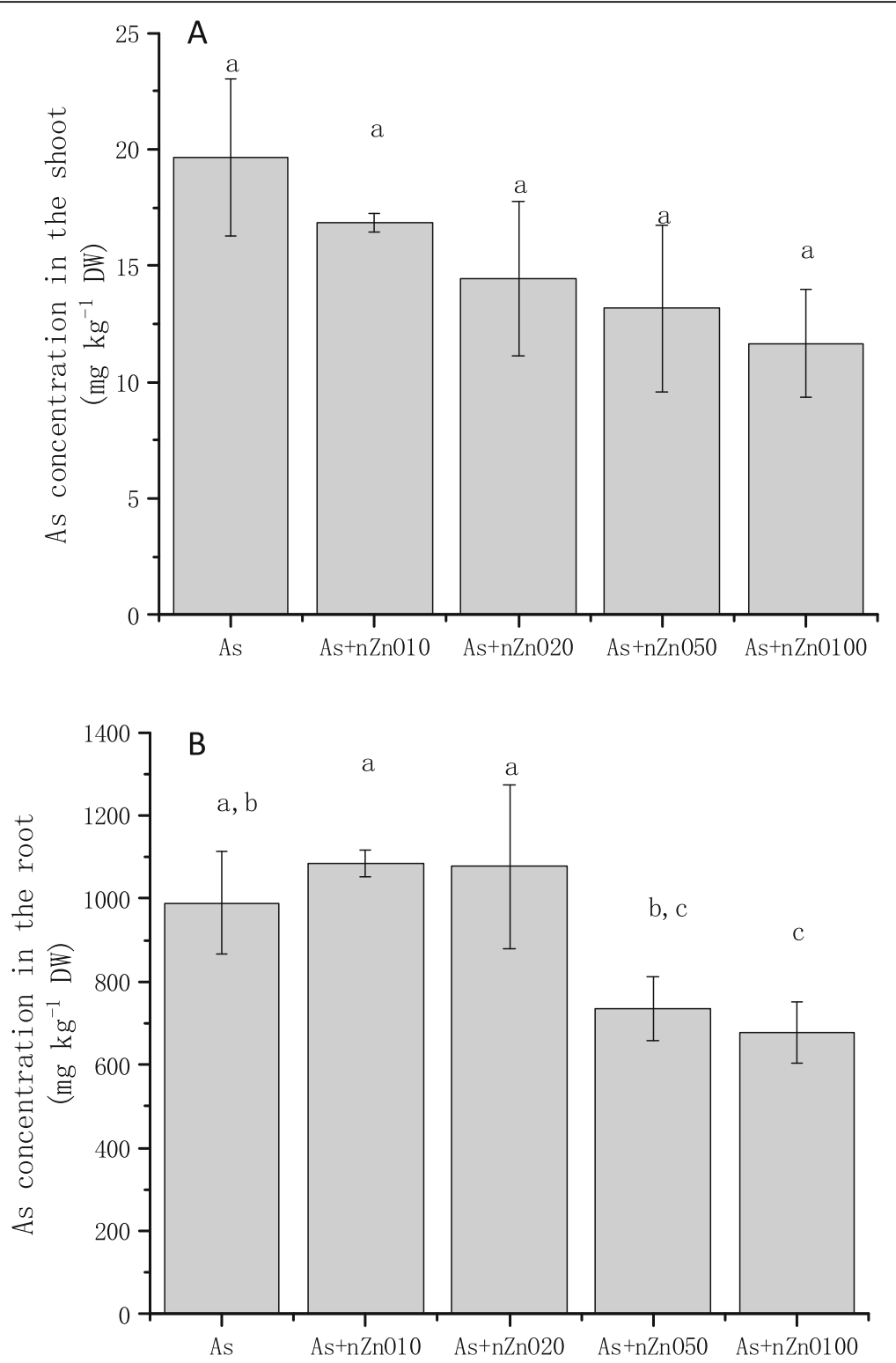

Fig. 6 As concentration in rice shoots (a) and roots (b)

$13.1-14.1 \%$ and shoot weight by $15.1-41.2 \%$, respectively [29]. It's reported that kinds of NPs increase the growth of plants under metal stress. For example, Liu et al. found that $\mathrm{nCuO}$ treatment promoted rice growth and reduced absorption of As [12]. Similarly, it's depicted that $\mathrm{nZnO}$ application improved the height, number of leaves, shoot and roots dry biomass of maize plants grown on a Cd-contaminated soil [19]. Studies have shown that Zinc NPs and Zn positively influenced the growth of sorghum and nutritional status of the plants $[30,31]$. Besides, the promoted biomass with $\mathrm{nZnO}$ application might be associated with the decreased metal stress in rice. At the same time, it can be inferred from Fig. 6 that when the amount of $\mathrm{nZnO}$ applied is greater than $100 \mathrm{mg} \mathrm{kg}^{-1}$, the As concentration in the shoots and roots will be further reduced, because more As will be adsorbed before entering the rice root, similar to our previous stuy [29]. But it also needs to be noted that high concentration of $\mathrm{nZnO}$ can cause poison to plants and reduce the biomass of rice.

Chlorophyll is an important substance for plants to absorb sunlight for photosynthesis. The amount of chlorophyll affects the growth rate of plants, so it can be used as an important indicator to measure the degree of stress of heavy metals on plants [32]. Research by Rahman et al. showed that the chlorophyll content in rice is positively correlated with shoots growth [33], which is consistent with our results. Arsenic interfere with the 

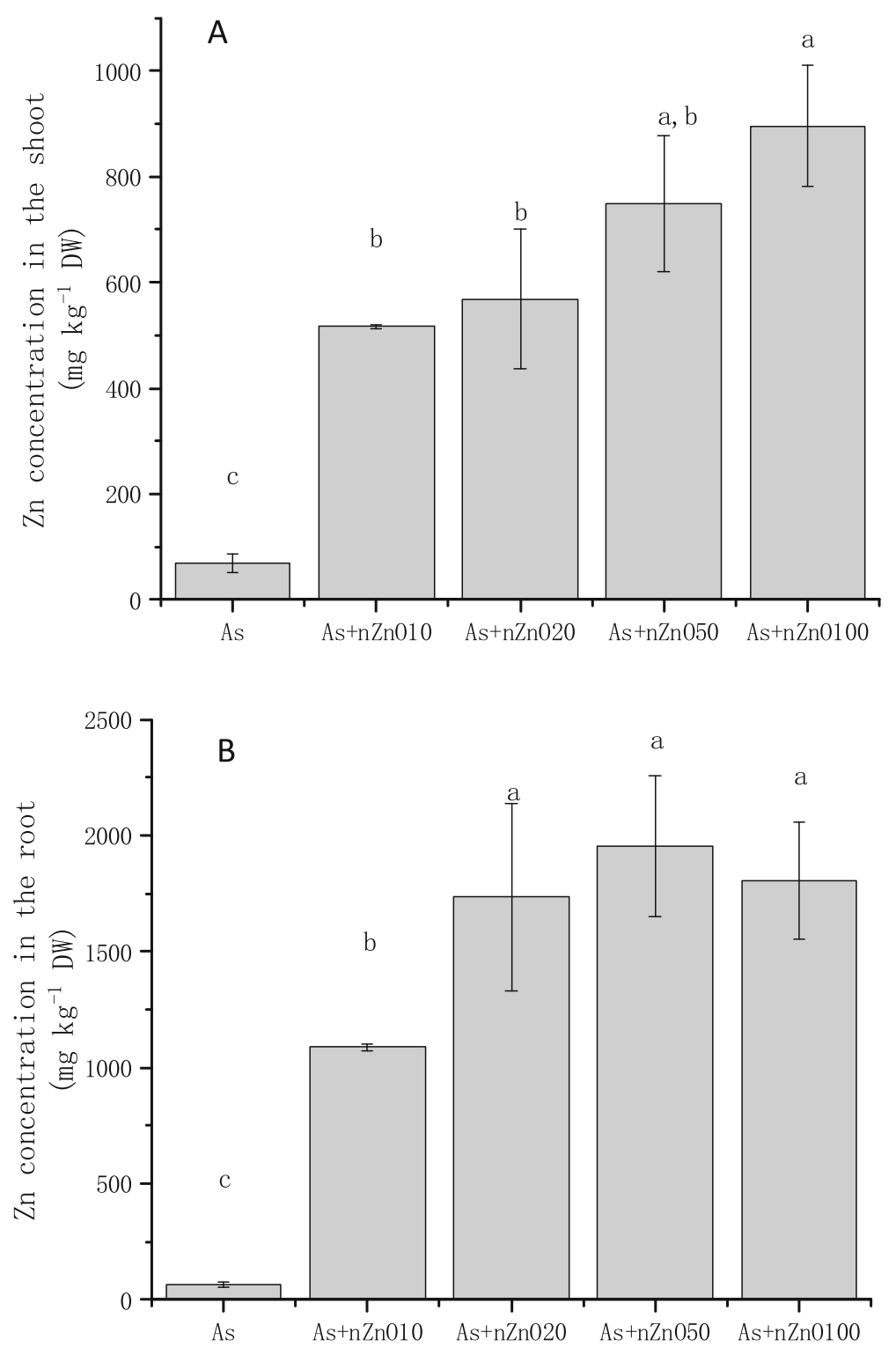

Fig. $7 \mathrm{Zn}$ concentration in rice shoots (a) and roots (b)

activity of chlorophyll synthase and hinder the synthesis of chlorophyll [34]. When the photosynthesis of the leaves is weakened, the carbohydrates produced are reduced so that the biomass of the shoots is decreased. The present study also indicated that with the application of $\mathrm{nZnO}(10-100 \mathrm{mg} / \mathrm{L})$, the chlorophyll concentration gradually increased, and the shoots biomass showed the same trend (Figs. 1 and 3). It's assumed that $\mathrm{Zn}$ plays a great role in photosynthesis induced the increase of chlorophyll concentration. Recent studies found that the application of $\mathrm{nZnO}$ increased the chlorophyll content of plants under $\mathrm{Cd}$ and $\mathrm{Pb}$ stress [17, 20].

Oxidative stress is generally considered to be possible mechanisms of phytotoxicity caused by heavy metals. The photosynthesis of chloroplasts is disturbed under arsenic, which causes oxygen to become its electron

Table 1 TF of the rice exposed to different treatments (mean $\pm S E, n=3$ )

\begin{tabular}{llllll}
\hline Treatment & As & As+nZnO10 & As+nZnO20 & As+nZnO50 & As+nZnO100 \\
\hline TF & $0.020 \pm 0.0011 a$ & $0.0155 \pm 0.0001 b$ & $0.0135 \pm 0.002 b$ & $0.0176 \pm 0.0037 \mathrm{~b} b$ & $0.0170 \pm 0.0017 \mathrm{~b}$ \\
\hline
\end{tabular}


Table 2 Summary of total arsenic and ratio of As (III) in rice tissues grown in different treatments (mean $\pm S E, n=3$ )

\begin{tabular}{llll}
\hline Treatment & Rice compartment & Total As $(\mathbf{m g} / \mathbf{k g}$ dry weight) & The ratio of As (III)(\%) \\
\hline As & Shoot & 19.67 & $99.58 \pm 1.15 \mathrm{~A}$ \\
As+nZnO10 & Shoot & 16.85 & $95.50 \pm 2.03 \mathrm{~B}$ \\
AstnZnO20 & Shoot & 14.44 & $95.90 \pm 2.35 \mathrm{~B}$ \\
As+nZnO50 & Shoot & 13.17 & $95.32 \pm 3.01 \mathrm{~B}$ \\
AstnZnO100 & Shoot & 11.66 & $95.01 \pm 2.85 \mathrm{~B}$ \\
As & Root & 989.38 & $99.01 \pm 6.03 \mathrm{a}$ \\
AstnZnO10 & Root & 1084.75 & $98.06 \pm 7.84 \mathrm{a}$ \\
As+nZnO20 & Root & 1077.04 & $99.30 \pm 10.10 \mathrm{a}$ \\
As+nZnO50 & Root & 736.08 & $98.68 \pm 5.32 \mathrm{a}$ \\
As+nZnO100 & Root & 677.22 & $99.32 \pm 8.32 \mathrm{a}$ \\
\hline
\end{tabular}

acceptor, and the metabolite ROS is also produced [35]. Subsequently, in order to prevent oxidative stress, plants can actively activate various enzyme and non-enzyme defense systems [36]. The SOD is the first defense enzyme that catalyzes the more toxic $\mathrm{O}_{2}^{-}$to less toxic $\mathrm{H}_{2} \mathrm{O}_{2}$ [37]. However, our results showed that $2 \mathrm{mg} / \mathrm{L} \mathrm{As}$ treatment decreased SOD activity compared with the control significantly (Fig. 5a). The reason might be that the high concentration of arsenic destroys the antioxidant reaction mechanism of rice. SOD activity increased with the addition of nano-zinc oxide, indicating that $\mathrm{nZnO}$ promoted the response of rice antioxidant mechanism. Due to the strong adsorption capacity of nano zinc oxide, arsenic is adsorbed before it enters the rice plant, thus protecting the antioxidant mechanism of rice [38]. Wang et al. found that SOD activity was upregulated by $\mathrm{nZnO}$ in tomato plants, supported by enhancing transcription of $\mathrm{Cu} / \mathrm{Zn} 2-\mathrm{SOD}$ and $\mathrm{Fe}-\mathrm{SOD}$ genes [39]. On the other hand, previous studies have reported that $\mathrm{nZnO}$ can promote the generation of ROS in rice plants [40]. This is consistent with the results that SOD activity decreased again when high concentration of

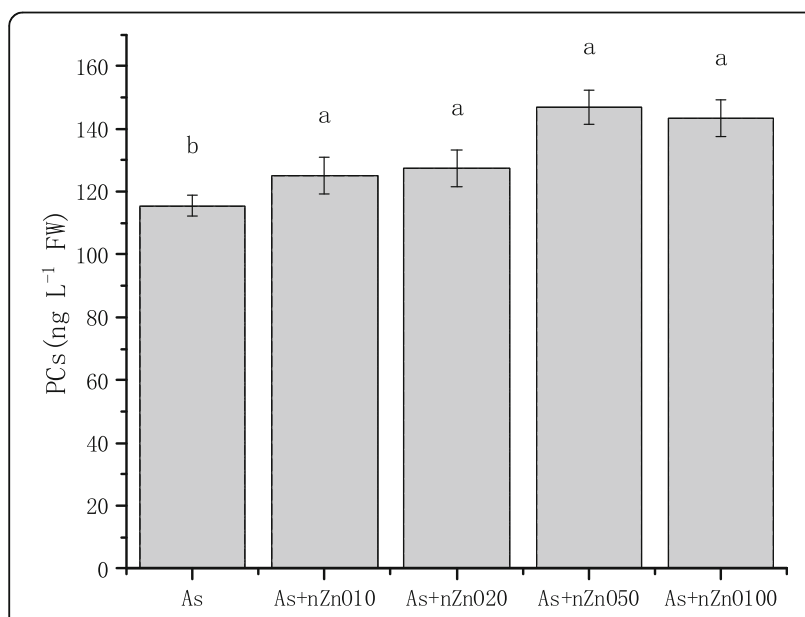

Fig. 8 Effects of different treatments on PCs content in rice roots
nZnO (20-100 mg/L) was added in our experiment. The following electrolyte leakage data also show that the addition $\mathrm{nZnO}$ of aggravated membrane lipid peroxidation. Differently, in our early germination experiments, CAT activity had the same trend with SOD activity, but it was not significantly affected in the current experiment.

The concentration of As in rice shoots decreased with the increase of $\mathrm{nZnO}$ concentration (Fig. 6a), while the As concentration in rice roots depended on the $\mathrm{nZnO}$ concentration. Low concentration $\mathrm{nZnO}(10-20 \mathrm{mg} / \mathrm{L})$ treatments increased the content of As in roots, but high concentration $\mathrm{nZnO}(50-100 \mathrm{mg} / \mathrm{L})$ treatments significantly reduced the concentration of As in the roots (Fig. 6b). To investigate the cause of this phenomenon in the roots, we studied the permeability of the root cell plasma membrane. The plasma membrane is selectively permeable, which controls the transport and exchange of substances inside and outside the cell. Electrolyte leakage was further used to detect the membrane permeability. The results of this study found that As treatment significantly disrupted the integrity of the root cell membrane and the application of $\mathrm{nZnO}$ aggravate the destruction of the root cell membrane (Fig. 4). This may be caused by high $\mathrm{Zn}$ concentration in the nutrient solution released by $\mathrm{nZnO}$ (Figure S2). As mentioned above, studies have found that excessive $\mathrm{Zn}$ can cause peroxidation of plant root membrane esters, leading to further damage to cell membranes [41]. Therefore, the application of low concentration $\mathrm{nZnO}(10-20 \mathrm{mg} / \mathrm{L})$ cannot reduce the absorption of As by roots. Although $50-100 \mathrm{mg} / \mathrm{L}$ $\mathrm{nZnO}$ application also aggravates the destruction of the root cell membrane, As concentration in the roots were significantly decreased because the As concentration in the nutrient solution was significantly decreased by the strong adsorption of $\mathrm{nZnO}(50-100 \mathrm{mg} / \mathrm{L})$ (Figure S1). Unlike the roots, As concentration in the shoots continued to decline with the $\mathrm{nZnO}$ increasing application. What happened when As transported from root to 
shoot? Transport factor (TF) was calculated, which is used to calculate the transport capacity of As in plants $[26,42]$. It's found that the $\mathrm{nZnO}$ application $(10-100$ $\mathrm{mg} / \mathrm{L}$ ) decreased As TF when rice was exposed to As stress. As speciation in rice tissues and PCs concentration in roots explained the phenomenon. We found that As speciation in rice roots and shoots was dominated by arsenite (95.01-99.58\%) as reported by other reports [43, 44]. There is no significant difference of the As speciation in the roots when rice plants treated with $\mathrm{nZnO}$, but arsenite percentages in the shoots were significantly decreased by $\mathrm{nZnO}$ application. Besides, we found that PCs concentration in rice roots were significantly upregulated by the $\mathrm{nZnO}$ application. So it's assumed that $\mathrm{nZnO}$ application up-regulates the PCs concentration in rice roots, causing more As (III) stored in the root cell vacuole in combination with PCs [45]. Then the As (III) transport to the shoot was suppressed, causing the arsenic concentration and the arsenite percentage also decreased in the shoots. Another possible reason is that the increase of $\mathrm{Zn}$ promoted the growth of plant shoots (Fig. 1), then the concentration of As in the shoots was diluted by the increasing biomass. The negative correlation between As concentration and $\mathrm{Zn}$ concentration also indicated that the addition of $\mathrm{nZnO}$ played a positive role in the reduction of arsenic in rice shoots.

On the other hand, the application of $\mathrm{nZnO}$ increases the concentration of $\mathrm{Zn}$ in rice shoots and roots (Fig. 6). Zinc concentration in shoots and roots of rice showed the increasing trend with $\mathrm{nZnO}$ applied. $\mathrm{nZnO}$ have been used as a source of fertilizer in many studies to improve plant growth $[15,46]$. It has been shown that application of $200 \mathrm{mg} / \mathrm{L}$ $\mathrm{nZnO}$ enhanced plant heights and plant weights approximately $105-113 \%$ and $122-160 \%$, respectively [47]. ZnO nanoparticles not only increase the bioaugmentation of $\mathrm{Zn}$ but also improve the nutritional quality of plants. For example, compared with the control, the addition of $\mathrm{nZnO}$ to tomatoes increases the lycopene content [48].

In summary, in this study, we found a significant effect of $\mathrm{nZnO}$ on rice seedling growth, biochemical reactions, and arsenic uptake. The results showed that $\mathrm{nZnO}$ can be used as a fertilizer to promote plant growth and decrease the accumulation of As in rice. According to the plant growth and As accumulation, the optimal concentration of $\mathrm{nZnO}$ is $100 \mathrm{mg} / \mathrm{L}$. A whole life cycle study in the soil system will be conducted to further determine the interaction of $\mathrm{nZnO}$ and $\mathrm{As}$ in plants.

\section{Supplementary Information}

The online version contains supplementary material available at https:/doi. org/10.1186/s12870-021-02929-3.

Additional file 1: Figure S1. The curve of the rate of As adsorption by different concentration of zinc oxide nanoparticles. Figure S2. As concentration in nutrient solution of different treatments when rice was harvested.

\section{Acknowledgements}

We thank the school of Resources and Environment, Anhui Agricultural University, Hefei, China for the assistance.

\section{Authors' contributions}

Wenling Ye and Xianjin Tang conceived and designed the study. Shiwei Yan, Fan Wu, Song Zhou, and Jianhao Yang performed the experiments. Wenling Ye wrote the paper. Xianjin Tang reviewed and edited the manuscript. All authors read and approved the manuscript.

\section{Funding}

We acknowledge Provincial Natural Science Foundation of Anhui (2008085MD112), the Fundamental Research Funds for the Central Universities (2019FZJD007), Anhui Science and Technology Major Project (No.18030701186) and the Open Fund of Anhui Province Key Laboratory of Farmland Ecological Conservation and Pollution Prevention (FECPP201904).

Availability of data and materials

The datasets used and/or analyzed during the current study are available from the corresponding author on reasonable request.

\section{Declarations}

Ethics approval and consent to participate Not Applicable.

Consent for publication

Not Applicable.

\section{Competing interests}

On behalf of all authors, the corresponding author (Wenling Ye) states that there is no conflict of interest.

Received: 23 December 2020 Accepted: 18 February 2021

Published online: 24 March 2021

\section{References}

1. Richard S. Food safety. Arsenic and paddy rice: a neglected cancer risk? Science. 2008:321(5886):184-5.

2. Zhao FJ, Zhu YG, Meharg AA. Methylated arsenic species in Rice: geographical variation, origin, and uptake mechanisms. Environ Sci Technol. 2013;47(9):3957-66. https://doi.org/10.1021/es304295n.

3. Williams PN, Villada A, Deacon C, Raab A, Figuerola J, Green AJ, et al. Greatly enhanced arsenic shoot assimilation in rice leads to elevated grain levels compared to wheat and barley. Environ Sci Technol. 2007:41(19):6854-9. https://doi.org/10.1021/es070627i.

4. Hojsak I, Braegger C, Bronsky J, Campoy C, Colomb V, Decsi T, et al. Arsenic in rice: a cause for concern. J Pediatr Gastroenterol Nutr. 2015;60(1):142-5. https://doi.org/10.1097/MPG.0000000000000502.

5. Wan YN, Camara AY, Huang QQ, Yu Y, Wang Q, Li HF. Arsenic uptake and accumulation in rice (Oryza sativa L.) with selenite fertilization and water management. Ecotoxicol Environ Saf. 2018;156:67-74. https://doi.org/10.101 6/j.ecoenv.2018.02.074

6. Huang $Q$, Liu Q Lin LN, Li FJ, Han YF, Song ZG. Reduction of arsenic toxicity in two rice cultivar seedlings by different nanoparticles. Ecotoxicol Environ Saf. 2018;159:261-71. https://doi.org/10.1016/j.ecoenv.2018.05.008.

7. Khan I, Ahmad A, Iqbal M. Modulation of antioxidant defence system for arsenic detoxification in Indian mustard. Ecotoxicol Environ Saf. 2009;72(2): 626-34. https://doi.org/10.1016/j.ecoenv.2007.11.016.

8. Várallyay S, Bódi É, Garousi F, Veres S, Kovács B. Effect of arsenic on dry weight and relative chlorophyll content in greeningmaize and sunflower tissues. J Microbiol Biotechnol Food Sci. 2015;4(Special issue 3):167-9.

9. Hartley WJ, Ainsworth G, Meharg AA. Copper- and arsenate-induced oxidative stress in Holcus lanatus L. clones with differential sensitivity. Plant Cell Environ. 2001;24(7):713-22. https://doi.org/10.1046/j.0016-8025.2001. 00721.x. 
10. Shri M, Kumar S, Chakrabarty D, Trivedi PK, Mallick S, Misra P, et al. Effect of arsenic on growth, oxidative stress, and antioxidant system in rice seedlings. Ecotoxicol Environ Saf. 2009;72(4):1102-10. https://doi.org/10.1016/j.ecoenv.2 008.09.022.

11. Sharma YC, Srivastava V, Singh VK, Kaul SN, Weng CH. Nano-adsorbents for the removal of metallic pollutants from water and wastewater. Environ Technol. 2009;30(6):583-609. https://doi.org/10.1080/09593330902838080.

12. Liu J, Simms M, Song S, King RS, Cobb GP. Physiological effects of copper oxide nanoparticles and arsenic on the growth and life cycle of rice ( Oryza sativa japonica 'Koshihikari'). Environ Sci Technol. 2018;52(23):13728-37. https://doi.org/10.1021/acs.est.8b03731.

13. Gong X, Huang D, Liu Y, Zeng G, Wang R, Xu P, et al. Roles of multiwall carbon nanotubes in phytoremediation: cadmium uptake and oxidative burst in Boehmeria nivea (L.) Gaudich. Environ Sci. 2019;6(3):851-62.

14. Singh J, Lee B-K. Influence of nano-TiO2 particles on the bioaccumulation of $\mathrm{Cd}$ in soybean plants (Glycine max): a possible mechanism for the removal of Cd from the contaminated soil. J Environ Manag. 2016;170:88-96. https:// doi.org/10.1016/j.jenvman.2016.01.015.

15. Munir T, Rizwan M, Kashif M, Shahzad A, Ali S, Amin N, et al. Effect of zinc oxide nanoparticles on the growth and $\mathrm{Zn}$ uptake in wheat by seed priming method. Dig J Nanomater Biostruct. 2018;13(1):315-23.

16. Wang XP, Yang XY, Chen SY, Li QQ, Wang W, Hou CJ, et al. Zinc oxide nanoparticles affect biomass accumulation and photosynthesis in Arabidopsis. Front Plant Sci. 2016;6:9.

17. Hussain A, Ali S, Rizwan M, Rehman MZU, Javed MR, Imran M, et al. Zinc oxide nanoparticles alter the wheat physiological response and reduce the cadmium uptake by plants. Environ Pollut. 2018;242(Pt B):1518-26. https:// doi.org/10.1016/j.envpol.2018.08.036.

18. Rizwan M, Ali S, Ali B, Adrees M, Arshad M, Hussain A, et al. Zinc and iron oxide nanoparticles improved the plant growth and reduced the oxidative stress and cadmium concentration in wheat. Chemosphere. 2019;214:26977. https://doi.org/10.1016/j.chemosphere.2018.09.120.

19. Rizwan M, Ali S, Rehman MZU, Adrees M, Arshad M, Qayyum MF, et al. Alleviation of cadmium accumulation in maize (Zea mays L.) by foliar spray of zinc oxide nanoparticles and biochar to contaminated soil. Environ Pollut. 2019:248:358-67. https://doi.org/10.1016/j.envpol.2019.02.031.

20. Ali S, Rizwan M, Noureen S, Anwar S, Ali B, Naveed M, et al. Combined use of biochar and zinc oxide nanoparticle foliar spray improved the plant growth and decreased the cadmium accumulation in rice (Oryza sativa L.) plant. Environ Sci Pollut Res. 2019;26(11):11288-99. https://doi.org/10.1007/ s11356-019-04554-y.

21. Wang X, Sun W, Zhang S, Sharifan $H$, Ma X. Elucidating the effects of cerium oxide nanoparticles and zinc oxide nanoparticles on arsenic uptake and speciation in Rice ( Oryza sativa) in a hydroponic system. Environ Sci Technol. 2018;52(17):10040-7. https://doi.org/10.1021/acs.est.8b01664.

22. Liu XL, Zhang SZ, Shan XQ, Zhu YG. Toxicity of arsenate and arsenite on germination, seedling growth and amylolytic activity of wheat. Chemosphere. 2005;61(2):293-301. https://doi.org/10.1016/j.chemosphere.2 005.01.088.

23. Ye W, Wu F, Zhang G, Fang Q, Lu H, Hu H. Decreases cadmium concentration in root but facilitates cadmium translocation from root to shoot in Rice. J Plant Growth Regul. 2019;10:422.

24. Su YH, McGrath SP, Zhao FJ. Rice is more efficient in arsenite uptake and translocation than wheat and barley. Plant Soil. 2010;328(1-2):27-34. https:// doi.org/10.1007/s11104-009-0074-2.

25. Lichtenthaler $\mathrm{KH}$, Wellburn RA. Determination of total carotenoids and chlorophylls $\mathrm{a}$ and b of leaf in different solvents. Biochem Soc Trans. 1985; 11(5):591-2.

26. Ye W, Guo G, Wu F, Fan T, Lu H, Chen H, et al. Absorption, translocation, and detoxification of $\mathrm{Cd}$ in two different castor bean (Ricinus communis $\mathrm{L}$.) cultivars. Environ Sci Pollut Res Int. 2018;25(29):28899-906. https://doi.org/1 0.1007/s11356-018-2915-0.

27. Liu CP, Wei L, Zhang SR, Xu XH, Li FB. Effects of nanoscale silica sol foliar application on arsenic uptake, distribution and oxidative damage defense in rice (Oryza sativa L.) under arsenic stress. RSC Adv. 2014;4(100):57227-34 https://doi.org/10.1039/C4RA08496A.

28. Ye WL, Wood BA, Stroud JL, Andralojc PJ, Raab A, McGrath SP, et al. Arsenic speciation in phloem and xylem exudates of Castor bean. Plant Physiol. 2010;154(3):1505-13. https://doi.org/10.1104/pp.110.163261.

29. Wu F, Fang Q, Yan SW, Pan L, Tang XJ, Ye WL. Effects of zinc oxide nanoparticles on arsenic stress in rice (Oryza sativa L.): germination, early growth, and arsenic uptake. Environ Sci Pollut Res. 2020;27(21):26974-81. https://doi.org/10.1007/s11356-020-08965-0.

30. Hart JJ, Welch RM, Norvell WA, Kochian LV. Transport interactions between cadmium and zinc in roots of bread and durum wheat seedlings. Physiol Plant. 2010;116(1):73-8

31. Dimkpa CO, White JC, Elmer WH, Gardea-Torresdey J. Nanoparticle and ionic Zn promote nutrient loading of Sorghum grain under low NPK fertilization. J Agric Food Chem. 2017;65(39):8552-9. https://doi.org/10.1 021/acs.jafc.7b02961.

32. Chen J, Dou RZ, Yang ZZ, You TT, Gao X, Wang L. Phytotoxicity and bioaccumulation of zinc oxide nanoparticles in rice (Oryza sativa L.). Plant Physiol Biochem. 2018;130:604-12. https://doi.org/10.1016/j.plaphy.2018.08. 019.

33. Rahman MA, Hasegawa H, Rahman MM, Islam MN, Miah MAM, Tasmen A. Effect of arsenic on photosynthesis, growth and yield of five widely cultivated rice (Oryza sativa L.) varieties in Bangladesh. Chemosphere. 2007; 67(6):1072-9. https://doi.org/10.1016/j.chemosphere.2006.11.061.

34. Stoeva N, Berova M, Zlatev Z. Physiological response of maize to arsenic contamination. Biol Plant. 2003;47(3):449-52.

35. Sharma I. Arsenic induced oxidative stress in plants. Biologia. 2012;67(3): 447-53. https://doi.org/10.2478/s11756-012-0024-y.

36. Takahashi MA, Asada K. Superoxide anion permeability of phospholipid membrane and chloroplast thylakoids. Arch Biochem Biophys. 1983;226(2): 558-66. https://doi.org/10.1016/0003-9861(83)90325-9.

37. Singh HP, Batish DR, Kohli RK, Arora K. Arsenic-induced root growth inhibition in mung bean (Phaseolus aureus Roxb.) is due to oxidative stress resulting from enhanced lipid peroxidation. Plant Growth Regul. 2007;53(1): 65-73. https://doi.org/10.1007/s10725-007-9205-z.

38. Singh N, Singh SP, Gupta V, Yadav HK, Ahuja T, Tripathy SS. Rashmi: a process for the selective removal of arsenic from contaminated water using acetate functionalized zinc oxide Nanomaterials. Environ Prog Sustain Energy. 2013;32(4):1023-9. https://doi.org/10.1002/ep.11698.

39. Wang XP, Li QQ, Pei ZM, Wang SC. Effects of zinc oxide nanoparticles on the growth, photosynthetic traits, and antioxidative enzymes in tomato plants. Biol Plant. 2018;62(4):801-8. https://doi.org/10.1007/s10535-0180813-4.

40. Sheteiwy MS, Dong O, An JY, Song WJ, Guan YJ, He F, et al. Regulation of ZnO nanoparticles-induced physiological and molecular changes by seed priming with humic acid in Oryza sativa seedlings. Plant Growth Regul. 2017;83(1):27-41. https://doi.org/10.1007/s10725-017-0281-4.

41. Michael PI, Krishnaswamy M. The effect of zinc stress combined with high irradiance stress on membrane damage and antioxidative response in bean seedlings. Environ Exp Bot. 2011;74:171-7. https://doi.org/10.1016/j.envexpbot.2011.05.016.

42. He JL, Li H, Luo J, Ma CF, Li SJ, Qu L, et al. A Transcriptomic network underlies microstructural and physiological responses to cadmium in Populus x canescens (1 C W ). Plant Physiol. 2013;162(1):424-39. https://doi. org/10.1104/pp.113.215681

43. Xu XY, McGrath SP, Zhao FJ. Rapid reduction of arsenate in the medium mediated by plant roots. New Phytol. 2007;176(3):590-9. https://doi.org/1 0.1111/j.1469-8137.2007.02195.x.

44. Zhao FJ, Ma JF, Meharg AA, McGrath SP. Arsenic uptake and metabolism in plants. New Phytol. 2009;181(4):777-94. https://doi.org/10.1111/j.1469-8137.2008.02716x.

45. Cornu JY, Bakoto R, Bonnard O, Bussière S, Coriou C, Sirguey C, et al. Cadmium uptake and partitioning during the vegetative growth of sunflower exposed to low $\mathrm{Cd} 2+$ concentrations in hydroponics. Plant Soil. 2016;404(1-2):263-75. https://doi.org/10.1007/s11104-016-2839-8.

46. Venkatachalam P, Priyanka N, Manikandan K, Ganeshbabu I, Indiraarulselvi P, Geetha N, et al. Enhanced plant growth promoting role of phycomolecules coated zinc oxide nanoparticles with P supplementation in cotton (Gossypium hirsutum L.). Plant Physiol Biochem. 2017;110:118-27. https:// doi.org/10.1016/j.plaphy.2016.09.004.

47. Samart S, Chutipaijit S. Growth of pigmented rice (Oryza sativa L. CV. Riceberry) exposed to ZnO nanoparticles. Mater Today. 2019;17:1987-94.

48. Raliya R, Nair R, Chavalmane S, Wang WN, Biswas P. Mechanistic evaluation of translocation and physiological impact of titanium dioxide and zinc oxide nanoparticles on the tomato (Solanum lycopersicum L.) plant. Metallomics. 2015;7(12):1584-94. https://doi.org/10.1039/C5MT00168D.

\section{Publisher's Note}

Springer Nature remains neutral with regard to jurisdictional claims in published maps and institutional affiliations. 